\title{
RESEARCH AND EDUCATION IN THE MEDICAL AREA
}

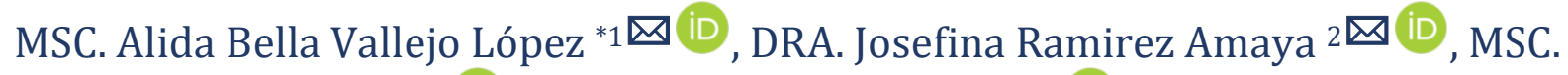
Juana Kou Guzman 3 (iD), ING. Cesar Noboa-Teran 4 (iD, MSC. Oswaldo Francisco Zavala Palacios 5 ⓘD, MSC. Narcisa Liliana Durán Ávila 6 (iD

$*_{1}^{*}, 2,3,4,5$ Guayaquil University, Faculty of Medical Sciences, Ecuador

${ }^{6}$ Laboratory Jesus De Nazareth, Faculty of Medical Sciences, Ecuador

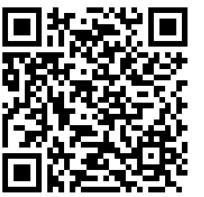

DOI: https://doi.org/10.29121/granthaalayah.v8.i9.2020.1353

Article Type: Research Article

Article Citation: MSC. Alida Bella Vallejo López, DRA. Josefina Ramirez Amaya, MSC. Juana Kou Guzman, ING. Cesar Noboa, MSC. Oswaldo Francisco Zavala Palacios, and MSC. Narcisa Liliana Durán Ávila. (2020). RESEARCH AND EDUCATION IN THE MEDICAL AREA. International Journal of Research -GRANTHAALAYAH, 8(9), 43-48.

https://doi.org/10.29121/granthaa layah.v8.19.2020.1353

Received Date: 31 August 2020

Accepted Date: 24 August 2020

Keywords:

Research

Education

Health

Medicine

\section{ABSTRACT}

The training of health professionals poses a great challenge in developing countries around the world. Medicine of the XXI century, represented in health careers, has a direct relationship with scientific and technical development, involves, observation, the search for knowledge about the problems that affect the health and biological well-being of the human being. This work implies a great ethical commitment to society, hence the importance of strengthening research capacity in both undergraduate and graduate studies. Developing human talent is a task that must be carried out continuously from the beginning of the medical career. Preserving life and preventing serious complications in the vulnerable population due to known or unknown pathologies is an unavoidable function of all health personnel, this is only achieved by training future professionals in the best way to guarantee the survival of future generations against the pathogenic microorganisms that can cause death. Teachers must implement the necessary strategies to motivate new professionals. Curiosity and interest must be strengthened throughout all medical careers.

\section{INTRODUCTION}

Research plays a decisive role in the learning process, to increase student knowledge, allowing comprehensive academic development. Research is considered an activity aimed at obtaining significant findings that increase human knowledge and science, promotes the development of skills and the discovery of new facts, technological advances. Bijarro, Francisco (2007):

It allows to develop improvements in all areas of knowledge; Thanks to research, it was possible to discover various inventions that are indispensable to society today. In this way, the researcher can understand the needs and problems that influence man's life. Research expands knowledge. Scientific development brings with it a cultural evolution for a better adaptation to the modern world.

(C) 2020 The Author(s). This is an open access article distributed under the terms of the Creative Commons Attribution License, which permits unrestricted use, distribution, and reproduction in any medium, provided the original author and source are credited. 
The benefits obtained range from economic growth to the discovery of new technologies that provide greater comfort to people and new treatments for diseases. Thousands of investigations could be mentioned that have changed the world, generating comforts. Going through the creation of the microscope, vaccines, X-rays, the decomposition of the atom, the study of DNA and the creation of new academic areas to learn about various topics, nothing would be the same, if it had not been investigated. (Vallejo A. 2020).

In a globalized context, research plays an important role in the training process of future professionals in the health area, considering that the area of medicine is constantly updating knowledge, methodologies and procedures, to improve the quality of healthcare processes. In addition, they must be informed of new health problems that arise in the world, considering that viruses, bacteria and microbial agents evolve and appear with increasing aggressiveness.

The current trend in the world is to conduct research of public utility, especially when it comes to biomedical research. Institutions must support not only theoretical academic training, but also training in the pillars of research such as the concepts of basic science and statistics, the mechanism by which the relevance of a medical or scientific study is presented or established, regardless of the area in which it has been developed.

The impulse for the development of research, on the part of doctors, must begin with profound modifications in the study plans of medical careers. The way we teach medicine and its related careers must be changed. Teaching should be presented as a guide to understanding, developing critical thinking, achieving independence of judgment, and preparing for change. Every medical student must be prepared to prevent and attend to the priority health problems of the population in an ethical framework, but also to develop their eventual capacity to carry out research, regardless of their final destination: generalist, specialist, Ph DV (Norero, Colomba. 2000).

\section{BACKGROUND}

Research is as old as humanity and has grown over time, like science to the present day. The emergence of the great philosophical, scientific and mathematical movements to understand the great phenomena of the world, from a deeper and more rational vision, had a great impulse after Christ.

Among the most prominent figures of scientists in the history of mankind who made contributions to scientific research, we can mention Galileo Galilei, considered the father of the scientific method, Hippocrates known as the father of medicine, among others.

The word investigate comes from the Latin investigare derived from vestigiun which means to look for a clue. (Universia México 2016) affirms that: Research is a quality of the human being, for the search for knowledge and truth. Investigating means searching and discovering, in order to develop new theories in different disciplines or modify existing ones. But this capacity, if it already exists in each person, must be developed, and the best way to do it is by promoting it from youth, through the development of academic papers.

For Carlos Borsotti (1989) “... research is a process through which an attempt is made to respond to scientific problems, through systematic procedures, which include the production of valid and reliable information". Therefore, research should be a fundamental educational practice for all students, especially in the medical education curriculum, both undergraduate and graduate.

Since Wilhelm Von Humboldt (1810) added research units to the university process, the value of the institutional mission of the University has increased, by generating new knowledge, to transcend and not remain stuck in theories considered as absolute truths. (Deiters, H. 1960).

This is another way to enrich future professionals educationally, to prepare them with the capacity for inquiry, to face the problems and challenges of science and society. (Naranjo R. 2013)

"The research allows to expand knowledge, based on data on any topic of social or scientific interest for academic purposes" (Coelho, 2019). Research requires time and dedication, the researcher must be interested in a topic and have a curiosity to investigate, in order to solve a puzzle. So, although all human beings have the ability to investigate, not everyone is interested in doing it, so it is clear that to investigate there must be motivation.

With the evolution of technologies, man adapts to new ways of communicating, studying and researching, everyone gets involved in one way or another in this new scheme of society, the digital age has come to stay, and while it has great advantages, it also has some disadvantages. This is evident in those people who have not yet mastered technology and computing, however it is important to join the new trend to constantly update. 
MSC. Alida Bella Vallejo López, DRA. Josefina Ramirez Amaya, MSC. Juana Kou Guzman, ING. Cesar Noboa, MSC. Oswaldo Francisco Zavala Palacios, and MSC. Narcisa Liliana Durán Ávila

Currently the world trend is network connectivity. Internet allows to know more quickly all the studies, discoveries and changes that occur every minute, knowledge evolves and science advances, everyone watches this change carefully. Despite this, few are interested in investigating. One of the highlights of information technology is that it turns out to be a very useful medium for researchers. The new era brings the creation of the "virtual university", before which some projections indicate the disappearance of the structure of the traditional university in its current configuration. The reason for this is that the "virtual university" has several advantages over the traditional one, as it encourages collaboration between universities and professors who are in remote locations, allowing students to easily access top-notch libraries from different institutions. (Akyeampong, 1998)

The number of medical researchers has decreased significantly in recent years, with a significant decrease in the interest of students to continue researching in their professional lives. "There is constant global concern about the decline of so-called 'medical researchers.' Students no longer perceive a career with solid research bases as viable for their professional future" (Herrera Miranda GL, 23 (2)).

\subsection{RESEARCH IN THE MEDICAL AREA}

Medicine, like all science, needs research to ensure advances in knowledge. Research in medicine contributes to: understanding the biological processes of the human being, carrying out prevention, detection, diagnosis, treatment and looking for the causes of diseases. Medical practice also includes the control of the health problems of the population.

To contribute to scientific advancement, there are various types of health research, such as biomedical, epidemiological, clinical, and health education research at the individual and population levels. It is important to recognize that there are health problems of various kinds, and to face them, learning in research during professional training must be valued.

All research must be carried out in accordance with scientific and ethical principles, both in the theoretical and in the experimental part, always having as a priority to avoid risks of all kinds to the life and integrity of people.

If there were no researchers in the medical area, we would not understand the complexity of the human body, nor would the function of each organ, the cure or treatment of diseases not have been found, there would be no vaccines, there would be no known DNA. They would not perform surgeries. Man is always exposed to diseases to investigate.

Research takes time, dedication and sacrifice and, in most cases, it is not rewarded. This leads to the need to train educators and other related professionals to learn theories, methods and research techniques, so that they can analyze and interpret in their professional contexts. (Martinez, G., 2007)

Society must understand and recognize that research is important in the life of man, it is the impulse that those who are inclined to investigate need. Medical personnel have the fundamental responsibility to protect, ensure, restore and guarantee health, this mission can only be effectively fulfilled by well-trained professionals both academically and ethically, with a vocation for service and with the desire to investigate to expand their services every day, services, knowledge. That the doctor is up to date will always be a professional, moral and social obligation.

\section{WHY DO UNIVERSITIES NEED TO INVESTIGATE?}

Research and education complement each other, especially in universities; since research is one of the fundamental pillars in the training of students, even more so in the area of health, because it allows increasing scientific production. The entities that regulate the quality of education in various countries of the world demand that education should be promoted beyond the classroom, the evaluation of a training center also depends to a large extent on how much it contributes to universal knowledge. These contributions help to improve the world by discovering and exploring new ways of solving everyday problems in the social field or of a biological nature in the area of medicine.

By definition, the university is the institution dedicated to higher education, (one that provides specialized knowledge of each branch of science) that is made up of several faculties and that grants the corresponding academic 
degrees. For his part (Albert, 2007) considers that "Research in general is an activity aimed at acquiring new knowledge; regardless of what that knowledge is, it can refer to the arts, letters or knowledge".

The university is the best place to promote scientific activity. In this way, it is possible to enrich production systems, obtain updated information and attract economic resources, as well as establish scientific projects with greater risk and potential return (Nuñez \& Montalvo, 2014). Universities must impact, leave a mark in a region or country, beyond graduates, and one way to do this is through research. (Mazuera Arias, R. 2016).

In the health area, the Medicine career and its related careers have the obligation to know health issues, so teaching, the most relevant content and research are important for better learning.

The student should not be a data bank, but a restless being, capable of questioning and solving problems (Norero V., Colomba. 2000). The development of investigative competences allows expanding the field of knowledge. In the 21st century, transformations are required to improve the educational-institutional model. (Gómez, J.; Diéguez, P.; Gómez 2014)

Universities are committed to promoting research, governments are favored by developing technological and scientific inventions for tomorrow, (Becker \& Pera Espinoza, 2019) express that "the economic success or failure of a nation no longer depends on technology or machinery that he owns, but what he does with his people". This suggests that the population generates economic and technological income for the benefit of a nation thanks to its contribution to the people through its research and that by working on this research topic, jobs are generated, increasing the value in the productive and economic system to improve, quality of life in all areas.

\section{VISION OF THE WORLD}

The countries' commitment must be aimed at promoting all fields of science, generating new knowledge and deepening existing ones. Any complete investigation will always be the starting point of a new investigation, expanding more and more the imagination, ideas, theories, of the phenomena that surround us.

The United Nations Educational, Scientific and Cultural Organization (UNESCO, 2013), in addition to China, the European Union, Japan, the Russian Federation and the United States still account for $72 \%$ of the world's research population. While in Latin America and South Asia they concentrate $8 \%$ and $23.3 \%$ of the world population of researchers, respectively, the more or less comparable mode is: $3.6 \%$ in the first and $3.1 \%$ in the second, which represents a low rate of researchers.

The National Science Foundation (National Science Board, 2018) published that the United States leads the world in research and development (R\&D) spending with 496,000 million dollars (26\% of the world total), followed by China with $21 \%$ ( $\$ 408$ billion).

In all areas of the university educational community, research work will always be productive for those involved, and it would be much more effective if it were implemented in the curricula, throughout all university careers. It is urgent, then, to promote research as a resource for the autonomous production of knowledge, which depends not only on the creation of individual and group expertise and learning, but also on the efficient management and organization of investigative processes

In developed countries there is evidence of the support given to researchers, however in developing countries much remains to be done. A change of mentality to facilitate administrative procedures such as the provision of infrastructure, in addition to financial support, this process should be seen as an investment, which will benefit the country.

A change in the focus of the subjects or courses taught in undergraduate becomes necessary to achieve a consolidated course of research fundamentals, as well as the dedication of a fixed time during the undergraduate career to achieve the necessary motivation in the student and that you undertake a research project on your own (or with a suitable mentor) and ultimately stand out. (Ávila, M.J. 2014)

\section{CONCLUSIONS}

The scientific advances achieved in the new century are the result of the work carried out by researchers, in all areas of knowledge.

Research in the new educational context is an indispensable factor for Higher Education Institutions, teachers must involve students in scientific activities, to strengthen the learning of future professionals. 
MSC. Alida Bella Vallejo López, DRA. Josefina Ramirez Amaya, MSC. Juana Kou Guzman, ING. Cesar Noboa, MSC. Oswaldo Francisco Zavala Palacios, and MSC. Narcisa Liliana Durán Ávila

In the medical area, there is a great responsibility to protect the life and health of the population, hence the importance of promoting a culture of researchers with ethical values, who provide new knowledge.

The countries that investigate generate knowledge that benefits society with technological and economic development and progress. All countries must adopt government and financial policies to support training programs and research skills development, providing infrastructure, legal resources and incentives to researchers, which will result in the well-being of the entire population.

\section{SOURCES OF FUNDING}

This research received no specific grant from any funding agency in the public, commercial, or not-for-profit sectors.

\section{CONFLICT OF INTEREST}

The author have declared that no competing interests exist.

\section{ACKNOWLEDGMENT}

None.

\section{REFERENCES}

[1] Akyeampong, D. (octubre de 1998). La educación superior y la investigación: Desafíos y oportunidades. Conferencia mundial sobre la educación superior. UNESCO, París

[2] Ávila, J.M. \& Rodríguez-Restrepo, A. (Noviembre 2014). La importancia de la investigación en el pregrado de medicina. MedWave 14 (10), pp. 1-12. Recuperado de: https://www.medwave.cl/link.cgi/Medwave/Revisiones/RevisionTemas/6032

[3] Albert, M. (2007). La Investigación Educativa: Claves Teóricas. Madrid: McGraw-Hill Interamericana de España. Obtenido de: http://webcache.googleusercontent.com/search?q=cache:http://dip.una.edu.ve/mpe/022metodologiaII/le cturas/Unidad\%2520I/Albert_La_Investigacion.pdf

[4] Becker, G., \& Pera Espinoza, C. (3 de Enero de 2019). UNINTERlingua. Obtenido de https://www.transformacion-educativa.com/index.php/articulos-sobre-educacion/54-importancia-de-lainvestigacion-educativa

[5] Bijarro, Francisco (2007): "Desarrollo estratégico para la investigación científica", Cancún, <www.eumed.net/libros-gratis/2007c/306/306.zip> [15/08/2016].

[6] Borsotti, Carlos. 1989. La situación problemática. El problema de investigación, Fichas de trabajo Universidad de Luján, Buenos Aires, Argentina.

http://www.transformacion-educativa.com/biblioteca-virtual-de-educacion/18-publicaciones-periodicasy-suplementos/54-insurgencia-magisterial-ano-1-no-

4\#: :text=investigar\%20es\%20un\%20proceso\%20por,de\%20informaci\%C3\%B3n\%20v\%C3\%A1lida\%20

y\%20confiable.\%E2\%80\%9D

[7] Coelho, F. (17 de Mayo de 2019). Significado de Investigación. Significados.com. Obtenido de: https://www.significados.com/investigacion/

[8] GOMEZ, J.; DIEGUEZ, P.; GOMEZ 2014 Motivando el interés por la investigación científica en estudiantes de educación media superior Congreso Iberoamericano de Ciencia, Tecnología, Innovación y Educación D ISBN: 978-84-7666-210-6 - Artículo 353 Buenos Aires Argentina Benemérita Universidad Autónoma de Puebla. México. file:///C:/Users/uf/Downloads/353.pdf

[9] Herrera Miranda, G. L. (Enero-Febrero 2015). ¿Por qué potenciar la formación en investigación para la integralidad del profesional de la Medicina? Revista de Ciencias Médicas de Pinar del Río 19 (1), pp. 9-12. Recuperado de: http://scielo.sld.cu/scielo.php?script=sci_arttext\&pid=S1561-31942015000100004 
[10] Martínez, G. R. A. 2007. La investigación en la práctica educativa: guía metodológica de la investigación para el diagnóstico y evaluación en los centros docentes. Ministerio de educación y ciencia dirección general de educación, formación profesional e innovación educativa Centro de Investigación y Documentación Educativa (CIDE). Colección investigamos No 5. Edita: (C) Secretaría General Técnica. Madrid.

[11] Mazuera Arias, Rina La investigación y las revistas científicas Revista Virtual Universidad Católica del Norte, núm. 47, febrero-mayo, 2016, pp. 1-3 Fundación Universitaria Católica del Norte Medellín, Colombia. http://www.redalyc.org/pdf/1942/194244221001.pdf

[12] Norero V., Colomba. (2000). Medicina y ciencia: una relación indispensable. Revista chilena de pediatría, 71(2), 81-82. https://dx.doi.org/10.4067/S0370-41062000000200001 https://scielo.conicyt.cl/scielo.php?script=sci_arttext\&pid=S0370-41062000000200001

[13] Universia México. (2016). La importancia de la investigación en las tareas universitarias. Recuperado de https://noticias.universia.net.mx/cultura/noticia/2016/11/04/1145206/importanciainvestigacion-tareasuniversitarias.html Padrón, J. 2007. Tendencias Epistemológicas de la Investigación Científica en el Siglo XXI

[14] Valdés Cuervo, A., \& Estévez Nenninger, E., \& Vera Noriega, J. (2013). Desarrollo de competencias científicas en estudiantes de posgrado desde la perspectiva del docente. Educere, 17 (58), 419430.http://www.redalyc.org/pdf/356/35630404005.pdf

[15] Vallejo López, A. (2020). El papel del docente universitario en la formación de estudiantes investigadores desde la etapa inicial. Educación Médica Superior, 34(2). Recuperado de http://www.ems.sld.cu/index.php/ems/article/view/1579

[16] Vallejo López, A., Daher Nader, J., \& Rincón Rios, T. (2020). Investigación y creatividad para el desarrollo de competencias científicas en estudiantes universitarios de la salud. EducacióN MéDica Superior, 34(3). Recuperado de http://www.ems.sld.cu/index.php/ems/article/view/1606/1033 